PRACE NAUKOWE UNIWERSYTETU EKONOMICZNEGO WE WROCLAWIU

\title{
Ksymena Rosiek
}

Uniwersytet Ekonomiczny w Krakowie

e-mail: ksymena.rosiek@uek.krakow.pl

\section{STRATEGIA UNII EUROPEJSKIEJ WOBEC KSZTALTOWANIA RACHUNKÓW EKONOMICZNYCH ŚRODOWISKA}

\section{THE STRATEGY OF THE EUROPEAN UNION TOWARDS THE DEVELOPMENT OF ENVIRONMENTAL ECONOMIC ACCOUNTS}

DOI: $10.15611 /$ pn.2017.478.33

JEL Classification: Q560, M480

Streszczenie: Rachunki ekonomiczne środowiska są modułem statystycznym umożliwiającym konwersję danych zgromadzanych w systemach statystycznych w użyteczne wskaźniki łączące dane związane ze środowiskiem z danymi gospodarczymi. Rachunki te, opierając się na nomenklaturze rachunków narodowych, umożliwiają lepszą ekstrapolację trendów, co z kolei jest niezbędne do korygowania kierunków i instrumentów polityki gospodarczej. Wszystkie wprowadzane w UE rozwiązania są zgodne z międzynarodowymi wytycznymi.. Niemniej jednak z faktu, że prace na tymi rachunkami prowadzone były równolegle na szczeblu międzynarodowym i unijnym, zrodził się pewien bałagan informacyjny. Artykuł ma więc charakter przeglądowy i porządkujący natłok informacji w tym temacie. Celem artykułu jest analiza strategii Unii Europejskiej w związku z kształtowaniem rachunków gospodarczych środowiska. Przeprowadzona została jednak znacznie szersza analiza dokumentów źródłowych, a nie tylko samych dokumentów programujących rozwój tych rachunków w UE, co umożliwia lepsze zrozumienie przyczyn tworzenia tych rachunków i ich odmienności względem tradycyjnych zasobów statystycznych.

Slowa kluczowe: Rachunki ekonomiczne środowiska (SEEA), Europejski system rachunków środowiska (ESEA).

Summary: Environmental Economic Accounts are a statistical module that makes it possible to convert the data collected in statistical systems into useful indicators linking data related to the environment with economic data. These accounts, based on the combined national accounts, allow for a better extrapolation of trends, which, in turn, is essential for the correction of economic policy directions and instruments. All the solutions introduced in the EU are in line with international guidelines. Nevertheless, the fact that these accounts were developed simultaneously at the international and EU levels, contributed to certain misrepresentations. This article therefore surveys the field with a view to organising the available information on the subject. The aim of the article is to analyse the strategy of the European Union related to 
the development of Environmental Economic Accounts. It is based on a much broader analysis of source documents, not only the relevant EU programming documents, which allows for a better understanding of the reasons behind creating these accounts and the ways in which they differ from traditional statistical resources.

Keywords: European Environmental Economic Accounts (EEEA), European System for Integrated Environmental Accounting (ESEA).

\section{Wstęp}

Wzrasta zapotrzebowanie na informacje statystyczne, zwłaszcza te odzwierciedlające tworzenie globalnego łańcucha wartości. Niezbędne jest więc pokazanie wkładu środowiska, sposobów jego wykorzystania w procesach gospodarczych. Wreszcie dane gromadzone we właściwych przekrojach umożliwiają lepszą ocenę skutków realizowanych polityk i tam, gdzie to możliwe, szybszą reakcję na te zmiany. Konieczne jest adekwatne czasowo dostarczanie spójnych danych o wysokiej jakości. Niezbędna jest więc wspólna metodologia, która od wielu lat jest rozwijana na poziomie rachunków narodowych. Odpowiedzią na potrzeby informacyjne w zakresie relacji środowisko-gospodarka jest system Rachunków ekonomicznych środowiska (SEEA), który jest obecnie międzynarodowym standardem. Z pewnością dostęp do bardziej aktualnych danych statystycznych dotyczących środowiska i jego relacji z gospodarką uwypuklił konieczność zmian w globalnych procesach gospodarowania, a jednocześnie dostrzeżono kolejne luki informacyjne, co przyspieszyło i zdynamizowało rozwój rachunków ekonomicznych środowiska w ostatnich latach.

Celem artykułu jest analiza strategii Unii Europejskiej w związku z kształtowaniem rachunków gospodarczych środowiska, w tym rachunków towarów i usług związanych z ochroną środowiska. Przeprowadzona została jednak znacznie szersza analiza dokumentów źródłowych, a nie tylko samych dokumentów programujących rozwój tych rachunków w UE, co umożliwia lepsze zrozumienie przyczyn tworzenia tych rachunków i ich odmienności względem tradycyjnych zasobów statystycznych.

Artykuł ma charakter przeglądowy i porządkujący natłok informacji w tym temacie, spowodowany równoległą pracą wielu instytucji nad tworzeniem standardów Rachunków ekonomicznych środowiska.

\section{Rozwój Rachunków ekonomicznych środowiska}

Za początkowy okres tworzenia Rachunków ekonomicznych środowiska można uznać lata 90., a istotnym punktem zwrotnym było powołanie w 1994 r. tzw. Grupy Londyńskiej [London Group... 1994]. Stworzone zostało forum dla praktyków i teoretyków oraz przedstawicieli organizacji międzynarodowych ustanawiających stan- 
dardy statystyczne do pracy nad tymi rachunkami. Grupa pracuje do dziś. W 2005 r. Organizacja Narodów Zjednoczonych (UN) powołała zespół ekspertów ds. rachunków ekonomicznych środowiska (UN Committee of Experts on Environmental-Economic Accounting, UNCEEA), którego celem było [UNCEEA 2005]:

- Włączenie Rachunków ekonomicznych środowiska i powiązanych statystyk do głównego nurtu badań.

- Uczynienie z Rachunków ekonomicznych środowiska międzynarodowego standardu.

- Wspieranie wdrażania tych rachunków w poszczególnych krajach.

Istotnym elementem podejmowanych działań było prowadzenie badań, tworzenie metodologii gromadzenia danych, testowanie proponowanych rozwiązań, harmonizowanie i monitorowanie danych. Publikowane są wytyczne i podręczniki umożliwiające wdrażanie zaleceń tych rachunków. W 2007 r. powstało Biuro, którego członkowie są wybierani spośród przedstawicieli krajowych organów statystycznych oraz organizacji międzynarodowych, i reprezentowany jest tam również Eurostat. Unia Europejska już wcześniej włączyła się w prace nad zazielenianiem statystyki narodowej.

Aby ułatwić percepcję w zakresie wytycznych dotyczących rachunków środowiska, rysunek 2 prezentuje w uproszczeniu zależności pomiędzy najważniejszymi wytycznymi w zakresie rachunków narodowych i rachunków środowiska na poziomie międzynarodowym i unijnym. Odnosi się on oczywiście do dokumentów aktualnych.

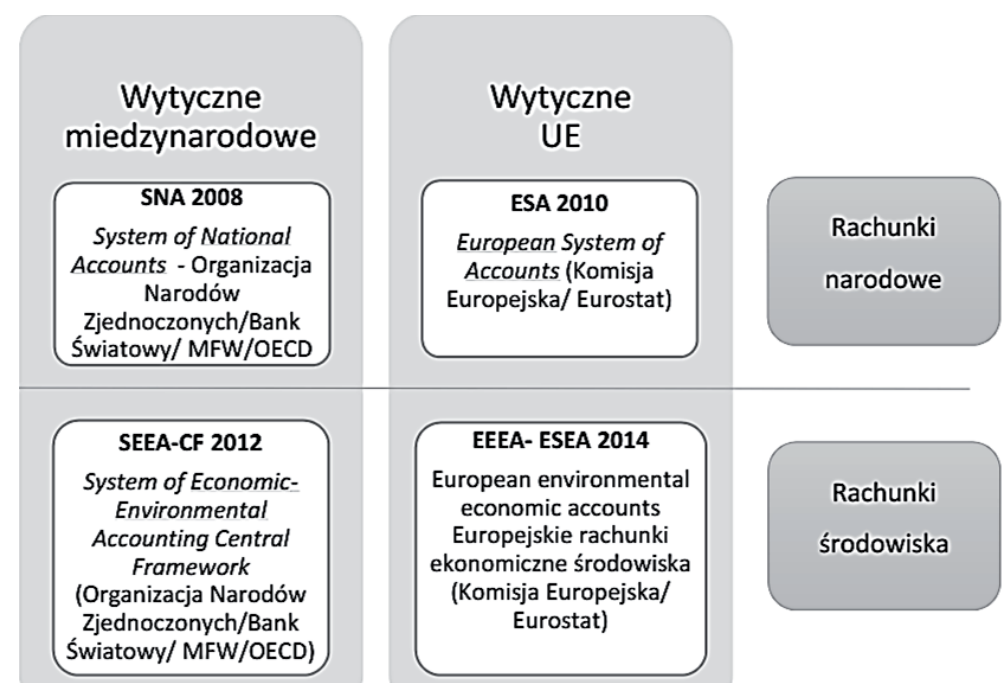

Rys. 1. Wytyczne odnośnie Rachunków ekonomicznych środowiska w strukturze rachunków narodowych Źródło: opracowanie własne na podstawie [European system of accounts 2012, ESEA 2014]. 
Unia Europejska równocześnie z pracami na forum międzynarodowym podejmowała działania w zakresie tych rachunków. Już w 1994 r. opublikowano komunikat określający kierunki działań dotyczące wskaźników środowiskowego i zielonych rachunków narodowych (Environmental Indicators and Green National Accounting) [Communication from the Commission 1994], w którym zakładano:

- Utworzenie i wzmocnienie ram dla zielonych rachunków narodowych poprzez większą integrację danych dotyczących wyników gospodarczych i presji na środowisko spowodowanych tą działalnością, w ramach Europejskiego systemu zintegrowanych wskaźników ekonomicznych i środowiskowych (European System of Integrated Economic and Environmental Indices, ESI).

- Wzmocnienie podstawowych prac nad rachunkami satelitarnymi wobec Rachunków narodowych (np. wydatki środowiskowe, utworzenie rachunków zasobów naturalnych, tworzenie metodologii szacowania strat środowiskowych i wyceny monetarnej).

W założeniach tworzona metodologia powinna umożliwić rozszerzanie rachunków o kwestie społeczne.

Jak widać, na tym etapie działano dwutorowo: z jednej strony proponowano rozszerzanie ram istniejących rachunków narodowych (tzw. zazielenianie PKB), $\mathrm{z}$ drugiej tworzenie podstaw pod rachunki satelitarne. Zaproponowano podejście w kilku krokach, polegające na [Communication from the Commission 1994, s. 5-6]:

- Stworzeniu i wykorzystaniu Europejskiego system wskaźników presji na środowisko (European System of Environmental Pressure Indices, ESEP) umożliwiającego tworzenie statystyk w jednostkach naturalnych.

- Połączenie wskaźników ESEP oraz danych istniejących w rachunkach narodowych (np. poprzez Europejski system gromadzenia informacji ekonomicznej o środowisku, European System for the Collection of Economic Information on the Environment [SERIEE 1994] w odniesieniu do gospodarki i w ten sposób rozbudowa i ujednolicenie Europejskiego systemu zintegrowanych wskaźników ekonomicznych i środowiskowych (European System of Integrated Economic and Environmental Indices, ESI).

- Kontynuacji prac nad metodologią wyceny szkód środowiskowych i wprowadzaniem tych informacji do ESI.

- Tworzeniu i rozbudowie środowiskowych rachunków satelitarnych na podstawie ESI.

- Koordynacji horyzontalnej podejmowanych działań.

- Stworzeniu usystematyzowanych podstaw, wspólnych wytycznych dla narodowej zielonej rachunkowości (national green accounting) w postaci wytycznych Europejskiego systemu rachunków środowiskowych (European System for Integrated Environmental Accounting, ESEA). 
Należy zaznaczyć, że w dokumentach unijnych, zwłaszcza w początkowej fazie rozbudowy rachunków ekonomicznych środowiska, czasami stosuje się zamiennie nazwy European System of Integrated Economic and Environmental Indices (ESI) oraz European System of Environmental Accounting (ESEA), lub nawet przypisuje zamiennie skróty, np. European System of Integrated Economic and Environmental Indices (ESEA), co wskazuje na płynny charakter tego procesu. Dziś ogromnie utrudnia poruszanie się w gąszczu nazw i skrótów.

Jednocześnie podejmowane działania opierały się na opublikowanych w $1993 \mathrm{r}$. wytycznych Systemu rachunków ekonomicznych środowiska (System of Environmental Economic Accounts, SEEA, aktualizowane kolejno w 2003 i 2012 r. [SEEA 2012]).

Opierając się zatem na tych wytycznych międzynarodowych (SEEA), Unia Europejska stworzyła strategię ich wdrażania: Europejską strategię rachunków środowiskowych (European Strategy for Environmental Accounts, ESEA), na bazie której tworzone są Europejskie rachunki ekonomiczne środowiska (European environmental economic accounts, EEEA; częściej stosowany skrót EEA).

\section{Cele i wyzwania Europejskich rachunków środowiska}

Pierwsze działania związane z rachunkami środowiskowymi i wskaźnikami ekologicznymi były już podejmowane w latach 90 . Natomiast pierwsza strategia europejskiego systemu rachunków środowiskowych (ESEA) została przyjęta w 2003 r., a poddana rewizji w 2008 r., co umożliwiło określenie szczegółowych potrzeb informacyjnych i wskazanie obszarów i kierunków rozwoju tych rachunków. Podstawą aktualnej Europejskiej strategii rachunków środowiskowych jest Europejski program statystyczny na lata 2013-2017 [Rozporządzenie Parlamentu Europejskiego i Rady z 15 stycznia 2013]. W programie tym zdefiniowano główne cele i kierunki rozwoju rachunków środowiskowo-gospodarczych (tab. 1). Część z tych celów jest już obecnie realizowana (o czym w następnej części artykułu). Szczególnie istotne wydają się kwestie związane $\mathrm{z}$ wdrażaniem kolejnych modułów rachunków ekonomicznych środowiska, integrowania informacji statystycznej i przestrzennej, tworzenia statystyk rolno-środowiskowych, podkreślenie istotności rachunków lasów, ale przede wszystkim zapowiedź podjęcia próby stworzenia nadrzędnego wskaźnika mierzącego globalne obciążenie środowiska [Eurostat, System of national accounts]. W zamierzeniach miałby to być wskaźnik, który byłby publikowany i analizowany razem z PKB oraz wraz ze wskaźnikami społecznymi. W ten sposób lepiej byłyby odzwierciedlane czynniki związane z dobrobytem. Wyzwaniem w zakresie gromadzenia danych dotyczących środowiska jest ich szybkie dostarczanie, a gdzie nie jest to możliwe, dokonywanie rzetelnych szacunków. Tylko wówczas taki wskaźnik, jak również szczegółowe wskaźniki rachunków ekonomicznych środowiska będą dobrym instrumentem monitorowania i korygowania kierunków polityki gospodarczej. 


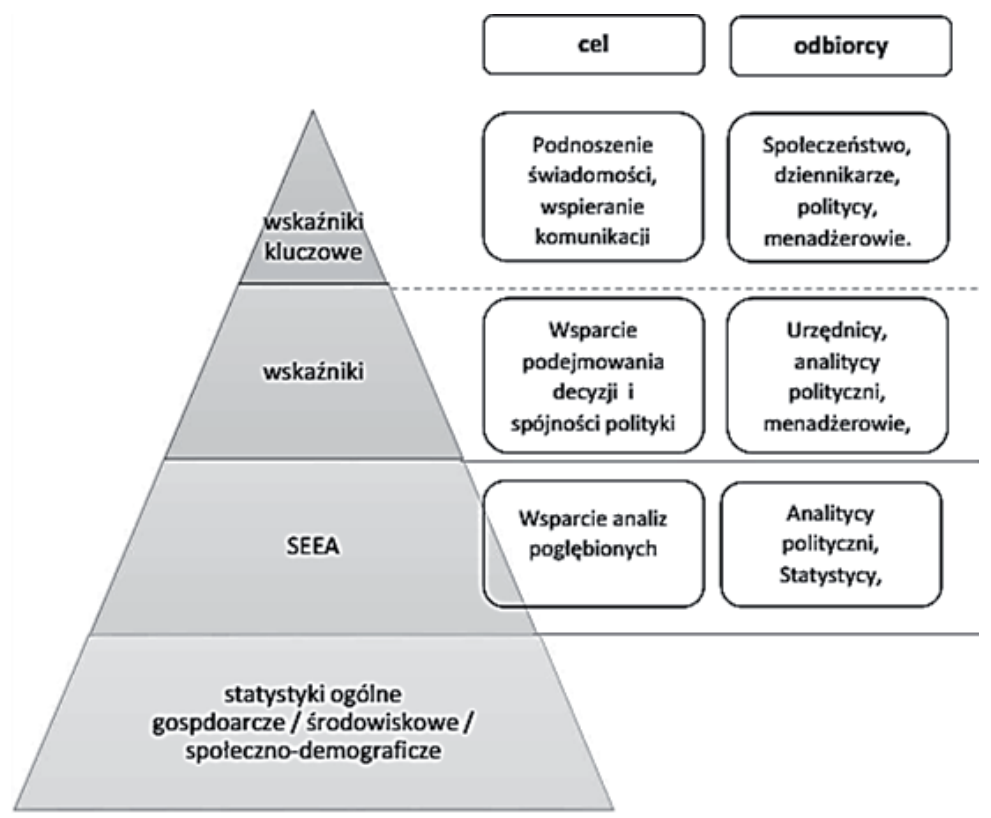

Rys. 2. Znaczenie danych z rachunków ekonomicznych środowiska w zaspokajaniu potrzeb informacyjnych interesariuszy

Źródło: [Eurostat, Pyramid Information].

Zaproponowane kierunki rozwoju Rachunków ekonomicznych środowiska na pewno pozwolą w lepszy sposób monitorować postawione cele związane z gospodarką niskoemisyjną i gospodarką o obiegu zamkniętym (circular economy).

Należałoby się zastanowić, jaka jest właściwie rola tych rachunków gospodarczo-środowiskowych. Dogłębna ich analiza stawia pod znakiem zapytania możliwość korzystania z nich przez szerokie grono interesariuszy. Można powiedzieć, że tworzone są one po to, by generować określone wskaźniki, umożliwiają przeorganizowanie dotychczas gromadzonych danych w systemach statystycznych, ich uwspólnianie, a tam, gdzie to konieczne, uzupełnienie. Zależności te i grupy docelowych adresatów prezentuje dobrze rysunek 2 .

W aktualnej Europejskiej strategii rachunków środowiskowych z 2014 r. zdefiniowano wyzwania, wśród których są [ESEA 2014]:

- Wzmacnianie jakości danych gromadzonych w ramach pierwszych wprowadzanych modułów rachunków ekonomicznych środowiska.

- Promowanie wykorzystania informacji dostarczanych przez ESEA.

- Poprawa terminowości i wprowadzanie wczesnych szacunków, aby umożliwić wykorzystywanie tych informacji statystycznych w życiu gospodarczym i kształtowaniu polityki gospodarczej.

- Wdrażanie kolejnych modułów rachunków. 
Tabela 1. Cele i działania w dziedzinie rachunków ekonomicznych środowiska zdefiniowane w Europejskim programie statystycznym

\begin{tabular}{|c|c|c|c|}
\hline Wyzwanie & Cel główny & Cel szczegółowy & Działania \\
\hline $\begin{array}{l}\text { Zrównoważenie } \\
\text { środowiskowe } \\
(2.2)\end{array}$ & $\begin{array}{l}\text { Ochrona, zachowanie } \\
\text { i poprawa jakości } \\
\text { środowiska dla obecnych } \\
\text { i przyszłych pokoleń } \\
\text { oraz zwalczanie skutków } \\
\text { zmian klimatu }\end{array}$ & $\begin{array}{l}\text { Zapewnienie rachunków } \\
\text { środowiska oraz statystyk } \\
\text { związanych ze zmianą klimatu, } \\
\text { z uwzględnieniem zjawisk } \\
\text { zachodzących w tej dziedzinie na } \\
\text { całym świecie } \\
\text { (cel } 2.2 .1)\end{array}$ & $\begin{array}{l}\text { - opracowanie spójnego systemu rachunków środowiska, obejmujących informacje } \\
\text { dot. emisji do atmosfery, zużycia energii, przepływów i rezerw materialnych } \\
\text { zasobów naturalnych i wody, handlu surowcami podstawowymi i krytycznymi, } \\
\text { podatków ekologicznych i wydatków na ochronę środowiska; } \\
\text { - udoskonalanie, opracowywanie, tworzenie i rozpowszechnianie wskaźników } \\
\text { pokazujących presje wtórne, wpływ zmian klimatu (w tym na zdrowie), obszary } \\
\text { szczególnie wrażliwe oraz postępy w dostosowaniu do zmiany klimatu; } \\
\text { - opracowanie nadrzędnego wskaźnika mierzącego globalne obciążenie środowiska }\end{array}$ \\
\hline \multirow[t]{3}{*}{$\begin{array}{l}\text { Statystyki } \\
\text { dotyczące } \\
\text { geoprzestrzeni, } \\
\text { środowiska, } \\
\text { rolnictwa } \\
\text { i inne statystyki } \\
\text { sektorowe } \\
(3.3)\end{array}$} & $\begin{array}{l}\text { Połączenie statystyki } \\
\text { z danymi zawierającymi } \\
\text { odniesienia przestrzenne } \\
\text { i analizą geoprzestrzenną } \\
\text { zapewni nowe } \\
\text { możliwości }\end{array}$ & $\begin{array}{l}\text { Kształtowanie polityki opartej na } \\
\text { faktach za pomocą połączonych } \\
\text { informacji przestrzennych } \\
\text { z danymi statystycznymi } \\
\text { dotyczącymi zjawisk społecznych, } \\
\text { gospodarczych i środowiskowych } \\
\text { (Cel 3.3.1) }\end{array}$ & $\begin{array}{l}\text { - dalszy rozwój, utrzymanie i funkcjonowanie infrastruktury informacji } \\
\text { przestrzennej we Wspólnocie Europejskiej (INSPIRE); } \\
\text { - udostępnienie szerokiego zakresu informacji geograficznych poprzez współpracę } \\
\text { z unijnymi programami na rzecz badań użytkowania gruntów i teledetekcji; } \\
\text { - zintegrowanie danych statystycznych, tworząc w ten sposób elastyczną strukturę } \\
\text { o wielu źródłach służącą zapewnieniu ukierunkowanej analizy przestrzenno- } \\
\text {-czasowej }\end{array}$ \\
\hline & $\begin{array}{l}\text { Utrzymanie i rozwijanie } \\
\text { statystyk dotyczących } \\
\text { energii, transportu } \\
\text { i polityki w zakresie } \\
\text { zmiany klimatu }\end{array}$ & $\begin{array}{l}\text { Dostarczanie statystyk w } \\
\text { dziedzinie energii i transportu, } \\
\text { mających na celu wsparcie polityk } \\
\text { Unii } \\
\text { (Cel 3.3.3) }\end{array}$ & $\begin{array}{l}\text { tworzenie i rozpowszechnianie statystyk na temat: } \\
\text { - energii odnawialnej; } \\
\text { - oszczędności energii/efektywności energetycznej; } \\
\text { - bezpieczeństwa transportu, mobilności pasażerów, pomiaru ruchu drogowego } \\
\text { i intermodalnego transportu towarowego }\end{array}$ \\
\hline & $\begin{array}{l}\text { Pełniejsze gromadzenie } \\
\text { danych dotyczących } \\
\text { rolnictwa, z naciskiem } \\
\text { na wymiary: } \\
\text { środowiskowy, związany } \\
\text { z różnorodnością } \\
\text { biologiczną/ } \\
\text { ekosystemami, } \\
\text { gospodarczy, dotyczący } \\
\text { zdrowia i bezpieczeństwa } \\
\text { ludzi oraz społeczny }\end{array}$ & $\begin{array}{l}\text { Dostarczanie statystyk } \\
\text { dotyczących rolnictwa, } \\
\text { rybołówstwa i leśnictwa w celu } \\
\text { opracowania i monitorowania } \\
\text { wspólnej polityki rolnej i } \\
\text { wspólnej polityki rybołówstwa } \\
\text { (Cel 3.3.4) }\end{array}$ & $\begin{array}{l}\text { - przegląd i uproszczenie danych dotyczących rolnictwa; } \\
\text { - ponowne opracowanie procesów gromadzenia danych dotyczących rolnictwa } \\
\text { w celu poprawy jakości i terminowości dostarczanych danych; } \\
\text { - przegląd systemu zarządzania danymi dotyczącymi użytkowania gruntów/ } \\
\text { pokrycia terenu oraz opracowania i wdrożenia nowego systemu na tej podstawie; } \\
\text { - wdrożenie systemu gromadzenia danych w zakresie spójnych wskaźników rolno- } \\
\text {-środowiskowych; } \\
\text { - zapewnienia właściwego podziału danych według regionów; } \\
\text { - wdrożenie i rozpowszechnienie zestawu najważniejszych danych dotyczących } \\
\text { leśnictwa, pochodzących ze zintegrowanej rachunkowości środowiskowej } \\
\text { i gospodarczej leśnictwa (IEEAF), takich jak obszar leśny, wielkość i wartość } \\
\text { drzewostanu, oraz rachunków ekonomicznych dla leśnictwa i wycinki drzew }\end{array}$ \\
\hline
\end{tabular}

Źródło: [Rozporządzenie Parlamentu Europejskiego i Rady z 15 stycznia 2013]. 
- Inwestowanie w infrastrukturę statystyczną, umożliwiającą lepszą dostępność danych o wyższej jakości.

Większość z tych celów jest w fazie realizacji. Szczególnie istotne wydaje się wspieranie mechanizmów zapewniających jakość, spójność i terminowość gromadzonych danych oraz promowanie ich wykorzystania pośród szerszej grupy interesariuszy.

\section{Wdrażanie i plany rozwoju rachunków ekonomicznych środowiska}

Europejskie rachunki ekonomiczne środowiska (EEEA) są więc zgodne z wytycznymi międzynarodowymi w tym zakresie oraz oczywiście współgrają z metodyką rachunków narodowych (rys. 1), czyli posługują się tą samą nomenklaturą, tymi samymi kategoriami: produkcją globalną, wartością dodaną, eksportem, importem, zatrudnieniem itp. Część rachunków jest prowadzona w jednostkach naturalnych. Monetaryzacja tych wartości jest dużym wyzwaniem.

W Unii Europejskiej zestawiane jest już sześć modułów Europejskich rachunków ekonomicznych środowiska, wprowadzonych w dwóch turach, w 2011 i 2014 r., a w roku 2017 zostaną ogłoszone kolejne trzy moduły, które będą wdrażane i sprawozdawane.

- Moduł I [Rozporządzenie Parlamentu Europejskiego i Rady z 6 lipca 2011]:

- rachunki emisji do powietrza (AEA),

- podatki związane ze środowiskiem według rodzajów działalności gospodarczej (TAXES),

- ogólnogospodarcze rachunki przepływów materialnych (MFA).

- Moduł II [Rozporządzenie Parlamentu Europejskiego i Rady z 16 kwietnia 2014]:

- rachunki wydatków na ochronę środowiska (EPEA),

- rachunki sektora towarów i usług związanych z ochroną środowiska (EGSS),

- rachunki fizycznych przepływów energii (PEFA).

Jednakże trzeba podkreślić, że rachunki modułu II po raz pierwszy będą obowiązkowo raportowane w 2017 r., do tej pory część krajów przesyłało dane eksperymentalnie. Obecnie więc nie można jeszcze wyciągać żadnych wniosków. Trwają rozważania i przygotowania do wdrażania kolejnego modułu trzech rachunków [Domańska 2013, s. 19]: rachunki wody, rachunki leśnictwa, rachunki odpadów, rachunki usług dostarczanych przez ekosystemy, rachunki dotyczące wykorzystania zasobów i wydatków na zarządzanie, transfery związane ze środowiskiem (subsydia), rachunki dotyczące zielonych zamówień publicznych, rachunki związane z adaptacją do zmian klimatu, ogólnogospodarcze rachunki zasobów naturalnych.

Podsumowując, należałoby zadać zasadnicze pytanie. Skoro od lat rozwijana jest statystyka środowiskowa, to czym różnią się od niej Rachunki ekonomiczne środowiska. Czy z obu systemów informacyjnych będziemy otrzymywać takie same dane? Otóż nie. Różnice najlepiej pokazać na przykładzie Rachunków emisji do 
powietrza wdrażanych w pierwszym module. W statystyce emisja gazów (Nationale emission inventories) dana emisja zostanie przypisana do kraju, w którym występuje (zasada terytorialna). Natomiast w Rachunkach ekonomicznych środowiska (EEEA) ta emisja zostanie przypisana do kraju, w którym podmiot gospodarczy odpowiedzialny za tę emisję jest rezydentem. W przypadku emisji z transportu różnice mogą być bardzo istotne, np. różnica w poziomie emisji rejestrowanym w obu typach statystyk dla Danii sięga 95\% ze względu na sektor transportu morskiego [Eurostat, Greenhouse gas emissions...]. Mimo że obecnie mamy dość dobrze rozwiniętą sprawozdawczość statystyczną z zakresu np. wody czy odpadów, nie zmienia to faktu, że trzeba będzie opracować nową metodykę zestawiania rachunków wody i rachunków odpadów zgodną z nomenklaturą rachunków narodowych. Wyraźnie wskazuje się, że braki w danych źródłowych (w systemie statystycznym) mogą wpłynąć na opóźnienie wdrażania tych rachunków [Report from the Commission... 2011].

Jakie są więc zalety tworzonych rachunków ekonomicznych środowiska? Dzięki takiej reorganizacji danych zbieranych w systemie statystycznym można powiązać oddziaływania z konkretnym rodzajem działalności gospodarczej znacznie bardziej szczegółowo i dzięki temu np. wyodrębnić sektory w największym stopniu odpowiedzialne za emisję gazów cieplarnianych czy też pobór wody. Dane powiązane są z pewnymi informacjami o charakterze społecznym, np. badając wzrost sektora towarów i usług środowiskowych, gromadzone są informacje o zatrudnieniu w tym sektorze. Stosując metodologie rachunków narodowych, można w większym zakresie estymować dane tam, gdzie to konieczne. Tworzone są podstawy do tworzenia prognoz nie tylko ekonomicznych (jak dotychczas), ale również środowiskowych, np. w zakresie przewidywanej presji transportu na środowisko albo zmian w zasobochłonności gospodarki. Pozwala też monitorować skuteczność niektórych instrumentów polityki ekologicznej, np. podatków ekologicznych. Dzięki temu poszerza się kontekst ekonomiczny o kontekst środowiskowy. Tak jak pokazano na rysunku 2 , rachunki ekonomiczne środowiska pozwalają transformować gromadzone w systemie statystycznym dane $\mathrm{w}$ przydatne $\mathrm{z}$ punktu widzenia polityki gospodarczej wskaźniki.

\section{Zakończenie}

Rachunki ekonomiczne środowiska są modułem statystycznym umożliwiającym konwersję danych zgromadzanych w systemach statystycznych w użyteczne wskaźniki łączące dane związane ze środowiskiem z danymi gospodarczymi, co umożliwia monitorowanie zmian. Rachunki te, opierając się na nomenklaturze rachunków narodowych, umożliwiają lepszą ekstrapolację trendów, co z kolei jest niezbędne do korygowania kierunków i instrumentów polityki gospodarczej. Chociaż ich początki datuje się na lata 90., to w ostatnich latach widoczne jest szczególne przyspieszenie $\mathrm{w}$ ich wdrażaniu. Związane jest to z rosnącymi potrzebami informacyjnymi wynikającymi ze zwrotu w strategicznych celach rozwojowych Unii Europejskiej w kierun- 
ku gospodarki zasobooszczędnej, efektywnej energetycznie, zdolnej do adaptacji do zmian klimatu, do gospodarki o obiegu zamkniętym.

Wszystkie wprowadzane w UE rozwiązania są zgodne z międzynarodowymi wytycznymi, wręcz trzeba zaznaczyć, że Eurostat podejmuje aktywną współpracę na tym polu. W roku 2014 Unia Europejska ogłosiła kolejną aktualizację Europejskiej strategii rachunków środowiskowych. O ile w pierwszych dokumentach programujących rozwój tych rachunków widać było jeszcze wyraźne rozdwojenie pomiędzy zazielenieniem PKB a tworzeniem rachunków satelitarnych, a o tyle obecnie wskazuje się na potrzebę tworzenia oddzielnego nadrzędnego wskaźnika mierzącego globalne obciążenie środowiska, który byłby publikowany wystarczająco często, by mógł być interpretowany wraz z PKB i wskaźnikami społecznymi.

Istnieją jednak pewne zagrożenia. Dane w systemie Rachunków ekonomicznych środowiska są organizowane w inny sposób niż w obecnych systemach statystycznych. Dane z modułu Rachunków ekonomicznych środowiska mogą się znacząco różnić w obu systemach w odniesieniu do podobnych wskaźników z powodu przyjęcia innych klasyfikacji. Publikowane są równocześnie. Świadomość istnienia Rachunków ekonomicznych środowiska i ich funkcji oraz tego, czym różnią się od statystyki narodowej, jest bardzo niska. Może to powodować pewną dezinformację. Niemniej jednak wydaje się, że korzyści płynące $\mathrm{z}$ lepszego powiązania danych środowiskowych z gospodarczymi są bezsprzeczne i jest to argument za dalszym tworzeniem i rozwijaniem tych rachunków.

\section{Literatura}

Communication from the Commission to the Council and the European Parliament, 1994 - Directions for the EU on Environmental Indicators and Green National Accounting - The Integration of Environmental and Economic Information Systems, com/94/ 670 final.

Domańska W., 2013, Europejskie rachunki ekonomiczne środowiska, zaprezentowano na konferencji Ekonomia i polityka zrównoważonego rozwoju. Teoria i ujęcie statystyczne, Białowieża, 6 grudnia 2013, http://bialystok.stat.gov.pl/gfx/bialystok/userfiles/_public/seminaria_i_konferencje/ w.domanska.pdf.

ESEA 2014, European Strategy for Environmental Accounts, ESSC 2014/21/24/EN.

European system of accounts - ESA 2010, 2012, Eurostat, http://ec.europa.eu/eurostat/web/products-manuals-and-guidelines/-/KS-02-13-269.

Eurostat, Greenhouse gas emissions by industries and households - Statistics Explained, http://ec.europa.eu/eurostat/statistics-explained/index.php/Greenhouse_gas_emissions_by_industries_and_ households (21.02.2017).

Eurostat, Pyramid Information, http://ec.europa.eu/eurostat/statistics-explained/index.php/File:Pyramid_information_1.png (15.02.2017).

Eurostat, System of national accounts - new directions, http://ec.europa.eu/eurostat/statistics-explained/ index.php/System_of_national_accounts_-_new_directions (16.02.2017).

Handbook of National Accounting - Integrated Environment and Economic Accounting, 2003, Series: F, no. 61, United Nations European Commission International Monetary Fund Organisation for Economic Co-operation and Development World Bank. 
Handbook of National Accounting: Integrated Environmental and Economic Accounting, 1993, UN.

London Group on Environmental Accounting, 1994, http://unstats.un.org/unsd/envaccounting/londongroup (15.02.2017).

Report from the Commission to the European Parliament and the Council Regulation (EU), 2011, no 691/2011 of the European Parliament and of the Council of 6 July 2011 on European environmental economic accounts, COM/2013/0864.

Rozporządzenie Parlamentu Europejskiego i Rady (UE) nr 538/2014 z 16 kwietnia 2014 r. zmieniające rozporządzenie (UE) nr 691/2011 w sprawie europejskich rachunków ekonomicznych środowiska, Dz.U. L 158 z 27.05.2014.

Rozporządzenie Parlamentu Europejskiego i Rady (UE) nr 691/2011 z 6 lipca 2011 r. w sprawie europejskich rachunków ekonomicznych środowiska, Dz.U. L 192 z 22.07.2011.

Rozporządzenie Parlamentu Europejskiego i Rady (UE) nr 99/2013 z 15 stycznia 2013 r. w sprawie Europejskiego programu statystycznego 2013-2017, Dz.U. Lz 201339 z 9.02, s. 29.

SEEA, 2012, The System of Environmental-Economic Accounting 2012 - Central Framework, UN-ECIMF-OECD-WB.

SERIEE, 1994, Europejski System Gromadzenia Informacji Gospodarczej o Środowisku/The European System for the Collection of Economic Information on the Environment, 1994, Office for Official Publications of the European Comunities, edition 2002.

UNCEEA, 2005, UN Committee of Experts on Environmental-Economic Accounting, http://unstats. un.org/unsd/envaccounting/ceea (16.02.2017). 